\title{
Soil Is Not a Reservoir for Phellinus noxius
}

\author{
Zong-Chi Wu, ${ }^{1}$ Ya-Yun Chang, ${ }^{1}$ Qiao-Juan Lai, ${ }^{1}$ Heng-An Lin, ${ }^{1}$ Shean-Shong Tzean, ${ }^{1}$ Ruey-Fen Liou, ${ }^{1}$ \\ Isheng J. Tsai, ${ }^{2}$ and Chia-Lin Chung ${ }^{1, \dagger}$
}

\author{
${ }^{1}$ Department of Plant Pathology and Microbiology, National Taiwan University, Taipei City 10617, Taiwan \\ ${ }^{2}$ Biodiversity Research Center, Academia Sinica, Taipei City 11529, Taiwan \\ Accepted for publication 1 October 2019.
}

ABSTRACT

\begin{abstract}
Phellinus noxius causes brown root rot (BRR) of diverse trees. Basidiospores and diseased host tissues have been recognized as important sources of $P$. noxius inoculum. This study aimed to understand whether $P$. noxius could occur or survive in soil without host tissues in the natural environment. Soil was sampled before and after the removal of diseased trees at eight BRR infection sites (total of 44 samples). No P. noxius colonies were recovered in soil plating assays, suggesting that no or little viable $P$. noxius resided in the soil. To know whether $P$. noxius could disseminate from decayed roots to the surrounding soil, rhizosphere and non-rhizosphere soils were sampled from another two infection sites. Although $P$. noxius DNA was detectable with specific primers, no $P$. noxius could be isolated, even from the rhizosphere soils around decayed roots covered with $P$. noxius mycelial mats. The association between viable
\end{abstract}

$P$. noxius and the presence of its DNA was also investigated using field soil mixed with $P$. noxius arthrospores. After $P$. noxius was exterminated by flooding or fumigation treatment, its DNA remained detectable for a few weeks. The potential of onsite soil as an inoculum was tested using the highly susceptible loquat (Eriobotrya japonica). Loquats replanted in an infection site that had been cleaned up by simply removing the diseased stump and visible residual roots remained healthy for a year. Taken together, P. noxius is not a soilborne pathogen, and diseased host tissues should be the focus of field sanitation and detection for BRR.

Keywords: brown root rot, dissemination, loquat, molecular detection, Phellinus noxius, rhizosphere, soil plating, survival
Brown root rot (BRR) is a tree disease caused by the white rot fungus Phellinus noxius (Corner) G Cunningham. P. noxius is widespread in forests, landscapes, and orchards in tropical and subtropical areas in East and Southeast Asia, Oceania, Africa, Central America, and the Caribbean (CABI 2019). P. noxius is pathogenic to a wide range of hosts, spanning $>200$ broadleaved and coniferous tree species in 59 families (Ann et al. 2002). Crossinoculation tests revealed the host nonspecificity of $P$. noxius, although varying levels of susceptibility were detected (Ann et al. 1999a; Chang 1995b; Nandris et al. 1987). Infection of P. noxius usually begins in roots, and sometimes, the mycelial mat spreads to the basal stem. The $P$. noxius-colonized root tissue gradually turns white and soft, with a distinct network of dark brown zone lines (Ann et al. 2002). The decayed roots can cause a significant reduction in physical support and the absorption of water and nutrients (Ann et al. 2002; Cherubini et al. 2002). Two types of aboveground symptoms have been observed for BRR. Tree species, such as loquat (Eriobotrya japonica), longan (Dimocarpus longan), and camphor tree (Cinnamomum camphora), show rapid decline, with the leaves turning reddish brown within a few months. Others, such as Chinese banyan (Ficus microcarpa), sugar apple (Annona squamosa), and carambola (Averrhoa carambola), show foliar chlorosis, thinning leaves, and defoliation, and the plants gradually decline within several months to years (Ann et al. 1999b, 2002; Chung et al. 2015, 2017). The diseased trees may eventually die or

†Corresponding author: C.-L. Chung; clchung@ntu.edu.tw

Funding: The work was funded by the Office of General Affairs, National Taiwan University and the Bureau of Animal and Plant Inspection and Quarantine (BAPHIQ), Council of Agriculture, Taiwan.

*The $\boldsymbol{e}$-Xtra logo stands for "electronic extra" and indicates that one supplementary figure and one supplementary table are published online.

The author(s) declare no conflict of interest.

(C) 2020 The American Phytopathological Society topple over in strong winds and heavy rains. BRR has caused considerable economic losses in orchards, nurseries, and landscapes in Taiwan (Chung et al. 2015), Hong Kong (Huang et al. 2016), Macao (Wu et al. 2011), the Ryukyu and Ogasawara Islands of Japan (Sahashi et al. 2012, 2015), and Australia (Schwarze et al. 2012). It is also a threat to public safety, because $P$. noxius infection is not easily noticed until the root system is largely damaged.

The disease cycle of $P$. noxius (Ann et al. 2002) is similar to that of other important root-rotting basidiomycetes, such as Phellinus sulphurascens, Phellinus werii, Armillaria mellea, and Heterobasidion annosum. P. noxius spreads from diseased trees, stumps, or colonized wood debris to adjacent trees by root contact (Ann et al. 2002; Chung et al. 2015). Basidiocarps of $P$. noxius were previously thought to be rarely seen in the field (Ann et al. 1999a; Chang 1995b; Hattori et al. 1996). However, we observed that, when $P$. noxius severely colonizes the stump or the roots and butt, basidiocarps can arise under warm and humid weather conditions. In a nationwide survey of Taiwan between 2007 and 2018, of a total of 2,287 BRR cases, Hsiao et al. (2019a) recorded 164 cases (approximately 7.2\%) of flat- or bracket-type $P$. noxius basidiocarps on different tree species. Population genetics analyses of $P$. noxius isolates from Taiwan and offshore islands of Japan using data from whole-genome sequencing and simple sequence repeat markers revealed highly diverse monokaryotic or heterokaryotic clones existing in discrete disease foci (Akiba et al. 2015; Chung et al. 2015, 2017). The genetic evidence, together with the observation of twig and stem infections by $P$. noxius in fields (Hsiao et al. 2019b), suggests that genetically variable basidiospores are responsible for long-distance dispersal and establishment of new infection sites. Long-distance dispersal via the transport of infected plants/stumps or colonized wood debris by human activities cannot be excluded (Chung et al. 2015).

The possibility of $P$. noxius dissemination via soil has also been speculated. A 2016 investigation in Hong Kong (Wang et al. 2016) revealed that $P$. noxius DNA could be detected by quantitative PCR (qPCR) from soils collected between a dead tree and a diseased tree (both with $P$. noxius infection) and under some trees without $P$. noxius infection. Based on the widespread occurrence of $P$. noxius 
DNA in soils, Wang et al. (2016) proposed that $P$. noxius is a soilborne pathogen and that soil may be an important reservoir for the infection and survival of $P$. noxius. The survivability of $P$. noxius in soils with different moisture levels has been evaluated in greenhouse tests by Chang (1996). In soil with a low moisture content, $P$. noxius basidiospores, arthrospores, and mycelia could survive for no longer than 4.5 months, 3.5 months, and 10 weeks, respectively; however, $P$. noxius survived well (recovery rates $>80 \%$ ) in artificially inoculated wood sections throughout the entire 2-year experiment. In a field test (Chang 1996), the recovery rates of $P$. noxius from naturally infected roots of dead trees remained $>50 \%$ for 10 years. The results suggested that colonized wood in soil plays a vital role in long-term survival of $P$. noxius. However, more evidence is needed to demonstrate whether $P$. noxius occurs or survives in soil without host tissues in the natural environment.

In this study, we intensively sampled the soils from BRR-infested sites (with and without basidiocarps) and tested the survivability of $P$. noxius by plating soil on selective medium. To determine whether $P$. noxius mycelia or any asexual propagules could disseminate from diseased roots to the surrounding soil, we examined the rhizosphere and non-rhizosphere soils of $P$. noxius-colonized residual roots and diseased roots of a living tree in the field. The association between the presence of $P$. noxius DNA and viable $P$. noxius was also investigated in an artificial system through time course testing of field soils mixed with $P$. noxius arthrospores after fumigation and flooding treatments. By cultivating highly susceptible indicator plants (loquat cuttings [Chou et al. 2019]) in a cleaned-up infection site, the potential of onsite soil as a source of inoculum for BRR was tested. The findings will promote the understanding of the biology and epidemiology of $P$. noxius, which is important for developing effective and environmentally friendly control strategies for BRR.

\section{MATERIALS AND METHODS}

Soil plating. Survival of $P$. noxius in soil was evaluated using the soil dilution plating method according to Chang (1996). A 10fold dilution of the test soil was prepared by mixing $5 \mathrm{~g}$ of soil with sterile distilled water $\left(\mathrm{dH}_{2} \mathrm{O}\right)$ to a final volume of $50 \mathrm{ml}$ in a falcon tube. The $10^{-1}$ soil suspension was then diluted to $10^{-2}, 10^{-3}$, and $10^{-4}$, and $100 \mu \mathrm{l}$ of each dilution was plated onto modified P. noxiusselective medium MA +5 (malt extract agar plus five chemicals) (20 g of malt extract, $20 \mathrm{~g}$ of agar, $10 \mathrm{mg}$ of benomyl, $10 \mathrm{mg}$ of dicloran, $100 \mathrm{mg}$ of chloramphenicol, $500 \mathrm{mg}$ of gallic acid, and $1 \mathrm{~g}$ of tergitol NP-7 per liter) (Chang 1995a). After a 1-week incubation in the dark at $30^{\circ} \mathrm{C}$, the colonies showing a dark reddish brown diffusion zone (indicating the oxidation of gallic acid by wood decay fungi) (Lee et al. 2014) were subcultured on new potato dextrose agar (PDA) plates. The colonies growing on PDA were examined again after incubation in the dark at $30^{\circ} \mathrm{C}$ for a week. The number of CFU of $P$. noxius per gram of soil was calculated.

Detection of $P$. noxius DNA in the soil and loquat roots. DNA in $0.5 \mathrm{~g}$ of air-dried soil was extracted using the Presto soil DNA extraction kit (Geneaid Biotech Ltd.) according to the manufacturer's instructions. DNA was eluted with $25 \mu \mathrm{l}$ of doubledistilled water $\left(\mathrm{ddH}_{2} \mathrm{O}\right)$ and stored at $-20^{\circ} \mathrm{C}$ until use (within a week). Loquat roots were ground into sawdust using the pulverizing machine RT-02B (Rong Tsong Pricison Technology Co.), and then, they were ground into fine powder with liquid nitrogen using a mortar and pestle. DNA in $0.5 \mathrm{~g}$ of pulverized root tissue was extracted following a modified CTAB protocol (Doyle and Doyle 1987), with $1 \mathrm{ml}$ of CTAB extraction buffer (2\% [wt/vol] hexadecyltrimethylammonium bromide [CTAB], 1.4 M NaCl, 20 mM EDTA [pH 8.0], 0.1 M Tris-HCl [pH 8.0], $2 \%$ polyvinylpyrrolidone [PVP], and $0.2 \%$ [vol/vol] 2-mercaptoethanol), $1 \mathrm{ml}$ of phenol/chloroform/isoamyl alcohol (PCI = 25:24:1 [vol/vol]), and $300 \mu \mathrm{l}$ of isopropanol. The PCI extraction was repeated twice, and ethanol precipitation was conducted according to standard procedures. The DNA pellet was resuspended in $50 \mu \mathrm{l}$ of sterile $\mathrm{ddH}_{2} \mathrm{O}$ and kept at $-20^{\circ} \mathrm{C}$ until use.

$P$. noxius was detected by PCR amplification with the specific primer pair G1-F (5'-GCCCTTTCCTCCGCTTATTG-3') and G1-R (5'-CTTGATGCTGGTGGGTCTCT-3') (Wang et al. 2016; Wu et al. 2009). The quality of DNA was evaluated by PCR amplification of fungi and plant internal transcribed spacer (ITS) regions using the primer pairs ITS5 (5'-GGAAGTAAAAGTCGTAACAAGG-3')/ ITS4 (5'-TCCTCCGCTTATTGATATGC-3') (White et al. 1990) and ITS-An5 (5'-CCTTATCATTTAGAGGAAGGAG-3')/ITS-An4 (5'-CCGCTTATTGATATGCTTAAA-3') (Cheng et al. 2016), respectively. Each PCR reaction contained $1 \mu \mathrm{l}$ of DNA, $10 \mu \mathrm{l}$ of Taq DNA Polymerase $2 \times$ Master Mix RED (Amplicon Inc.; containing $150 \mathrm{mM}$ Tris- $\mathrm{HCl}$ [pH 8.5], $40 \mathrm{mM}\left(\mathrm{NH}_{4}\right)_{2} \mathrm{SO}_{4}, 3 \mathrm{mM} \mathrm{MgCl} 2,0.2 \%$ Tween 20, $0.4 \mathrm{mM}$ dNTPs, $0.05 \mathrm{U} / \mu \mathrm{l}$ of Taq DNA polymerase, inert red dye, and stabilizer), $1 \mu \mathrm{l}$ of $10 \mu \mathrm{M}$ forward primer, $1 \mu \mathrm{l}$ of $10 \mu \mathrm{M}$ reverse primer, and $7 \mu \mathrm{l}$ of $\mathrm{ddH}_{2} \mathrm{O}$. The thermal cycling parameters were 1 cycle of $94^{\circ} \mathrm{C}$ for $3 \mathrm{~min}$ and 30 cycles of $94^{\circ} \mathrm{C}$ for $30 \mathrm{~s}, 56^{\circ} \mathrm{C}$ for $30 \mathrm{~s}$, and $72^{\circ} \mathrm{C}$ for $1 \mathrm{~min}$ followed by a final extension step of $72^{\circ} \mathrm{C}$ for $5 \mathrm{~min}$. PCR products were analyzed by electrophoresis in a $1 \%$ agarose gel in 1× Tris-acetate-EDTA buffer and run for 25 to $30 \mathrm{~min}$ at $100 \mathrm{~V}$. Gels were stained with ethidium bromide and then, photographed using the Gel Documentation-VideGel VGIS-4 system (Top Bio Co.).

Isolation of $P$. noxius from the soil at eight BRR infection sites. Soil plating was conducted to isolate $P$. noxius from the soils at eight BRR infection sites ( Taiwan University (NTU) (Table 1 and Supplementary Fig. S1). The tree at each site was diagnosed with BRR based on typical signs

TABLE 1. Experimental sites on the campus of National Taiwan University

\begin{tabular}{|c|c|c|c|c|c|}
\hline \multirow[b]{2}{*}{ Site $^{\mathrm{a}}$} & \multirow[b]{2}{*}{ Tree species } & \multirow{2}{*}{$\begin{array}{l}\text { Removal of the diseased } \\
\text { stump (date) }\end{array}$} & \multicolumn{3}{|c|}{ Assay used to detect Phellinus noxius in this study ${ }^{\mathrm{b}}$} \\
\hline & & & Soil plating & DNA detection & Indicator plant \\
\hline$\overline{\mathrm{A} 1}$ & Ficus benjamina & October $2014^{c}$ & $\mathrm{~V}$ & - & - \\
\hline A2 & Ficus benjamina & 6 May 2015 & $\mathrm{~V}$ & - & - \\
\hline A4 & Ficus benjamina & 6 May 2015 & V & - & - \\
\hline A5 & Ficus benjamina & 16 October 2015 & V & - & - \\
\hline A6 & Ficus microcarpa & 16 October 2015 & $\mathrm{~V}$ & - & - \\
\hline $\mathrm{B} 1$ & Heritiera littoralis & 4 December 2018 & $\mathrm{~V}$ & $\mathrm{~V}$ & - \\
\hline B2 & Ficus microcarpa & 16 September 2018 & $\mathrm{~V}$ & $\mathrm{~V}$ & - \\
\hline $\mathrm{C} 1$ & Delonix regia & 30 May 2018 & $\mathrm{~V}$ & $\mathrm{~V}$ & $\mathrm{~V}$ \\
\hline $\mathrm{C} 2$ & Ficus benjamina & - & $\mathrm{V}$ & $\mathrm{V}$ & $\mathrm{V}$ \\
\hline
\end{tabular}

${ }^{a} \mathrm{~A} 1$ to $\mathrm{A} 8, \mathrm{~B} 1, \mathrm{~B} 2$, and $\mathrm{C} 1$ are brown root rot infection sites. Basidiocarps of P. noxius were observed at sites A7 and A8. Site C2 is P. noxius free.

b The assay was conducted (V) or not (-) for the experimental site.

c The exact date is unknown. 
and symptoms (such as a $P$. noxius mycelial mat and white rot with brownish hyphal cords) and the isolation of $P$. noxius from infected tissues (using the tissue isolation method described by Chou et al. [2019]). Basidiospores of $P$. noxius were observed at sites A7 and A8. The locations, host tree species, and dates of the removal of diseased stumps are listed in Table 1. From each infection site, the soils were sampled two to nine times, mostly at approximately 1- or approximately 2-month intervals after the stump removal (Fig. 1; the exact dates of sample collection are in Supplementary Table S1). Each time, soils from depths of 0 to 20 and 20 to $40 \mathrm{~cm}$ were collected from six randomly chosen spots at each site. The soils were pooled and evenly mixed together. The pooled sample was sieved through a mesh (aperture size: $2 \times 2 \mathrm{~mm}$ ) to remove soil clumps and residual roots; then, it was air dried for 1 day. Three replicates of soil plating were performed as described above, with aliquots of each dilution $\left(10^{-1}\right.$ and $\left.10^{-2}\right)$ spread onto five plates of $\mathrm{MA}+5$ medium in each replicate.

Isolation of $P$. noxius and detection of $P$. noxius DNA from the rhizosphere and non-rhizosphere soil in two BRR infection sites. Soils from another two BRR infection sites (sites B1 and B2) on the NTU campus were examined by soil plating as well as DNA detection (Table 1 and Supplementary Fig. S1). The trees at both sites were confirmed positive for $P$. noxius infection by the presence of BRR symptoms/signs, root tissue isolation, and molecular diagnosis using G1-F/G1-R primers as described above. The diseased tree, Heritiera littoralis, was alive at the $\mathrm{B} 1$ site. At the $\mathrm{B} 2$ site, the diseased tree, F. microcarpa, was removed 60 days before sample collection (sampling was done on 15 November 2018). Three rhizosphere and three non-rhizosphere soil samples were randomly collected from each site (Fig. 2A and B). Rhizosphere soil samples were collected from approximately $0.5 \mathrm{~cm}$ around the diseased roots (roots of the living tree [Fig. 2C] or the residual roots). Soil plating was performed as described above, with aliquots of each dilution $\left(10^{-1}\right.$ and $\left.10^{-2}\right)$ spread onto five plates of MA +5 medium. Soil DNA extraction $(0.5 \mathrm{~g}$ of soil per sample $)$ and detection of $P$. noxius DNA were conducted as described above.

Assay of $P$. noxius viability and detection of its DNA. The experiment was performed using field soil mixed with $P$. noxius arthrospores. The soil was collected from a site (C2) on the NTU campus without BRR-infected trees (Table 1 and Supplementary Fig. S1), sieved through a mesh (aperture size: $2 \times 2 \mathrm{~mm}$ ), and air dried for 1 day. P. noxius A42, which is a single-basidiospore isolate collected from Daxi, Yilan County in Taiwan, was cultured on 2\% water agar medium at $30^{\circ} \mathrm{C}$ in the dark for 2 weeks. After harvesting the arthrospores in sterile $\mathrm{dH}_{2} \mathrm{O}$, the concentration of the suspension was determined using a hemocytometer.

The pot assay involved four treatments: (i) without spores: soil alone (soil water content was adjusted to $10 \%$ [wt/wt]); (ii) spores: arthrospores were mixed homogenously with the soil $\left(3 \times 10^{5}\right.$ spores per $1 \mathrm{~g}$ of dried soil), and the soil water content was adjusted to $10 \%$

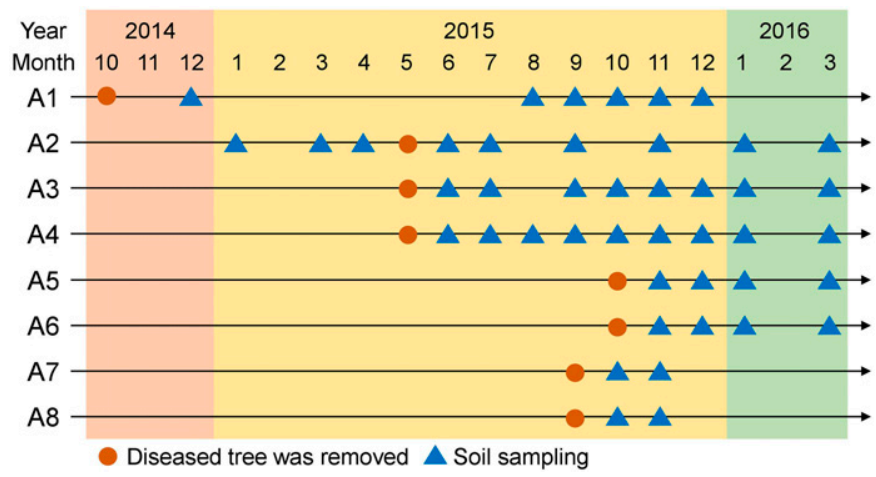

Fig. 1. Timeline of sample collection from brown root rot infection sites A1 to A8. Orange circles indicate the dates when the diseased trees were removed. Blue triangles indicate the dates when soil was sampled. Sites A7 and A8 were the two infection sites where Phellinus noxius basidiocarps were observed. (wt/wt); (iii) flooding treatment (spores + flooding): arthrospores were mixed with the soil $\left(3 \times 10^{5}\right.$ spores per $1 \mathrm{~g}$ of dried soil), and then, the soil water content was adjusted to $100 \%$ (wt/wt); and (iv) fumigation treatment (spores + fumigation): arthrospores were mixed with the soil $\left(3 \times 10^{5}\right.$ spores per $1 \mathrm{~g}$ of dried soil $)$, dazomet was added ( $25 \mathrm{mg}$ per $100 \mathrm{~g}$ of dried soil; approximately $60 \mathrm{~g} / \mathrm{m}^{3}$ of soil), and the water content was adjusted to $50 \%$ (the conditions for dazomet fumigation were the same as those described by Fu et al. [2012]).

For all treatments, soil samples were incubated in sealed plastic containers at $30^{\circ} \mathrm{C}$ in the dark $(100 \mathrm{~g}$ of dried soil per container and three containers [replicates] per treatment). A 1-day aeration was conducted after 2 weeks of fumigation with dazomet. Soils were sampled prior to the flooding or fumigation treatment $(0)$ and after 2 , 4 , and 8 weeks of incubation. Soil plating ( $5 \mathrm{~g}$ of soil from each container) was performed as described above, with aliquots of each dilution $\left(10^{-1}, 10^{-2}, 10^{-3}\right.$, and $\left.10^{-4}\right)$ spread onto five plates of MA + 5 medium. The dilution that resulted in the highest number of colonies was used to determine the CFU of P. noxius. The data were plotted in a line chart using Prism 8 (GraphPad Software Inc.). One-way analysis of variance was performed on the soil plating data. Differences among the quantities of $P$. noxius in four treatments at different time points were analyzed by Tukey's honestly significant difference test at $P<0.05$ using SAS Enterprise Guide 6.1 (SAS Institute Inc.). Soil DNA extraction ( $0.5 \mathrm{~g}$ of soil from each container) and detection of $P$. noxius DNA were conducted as described above.

Use of loquat to detect $P$. noxius inoculum in soil. Loquat was found to be one of the most highly susceptible hosts among the 101 horticultural woody plant varieties ( 92 species) tested (Ann et al. 1999b). Loquat cuttings inoculated with $P$. noxius-colonized wheatoat grains from roots showed typical quick decline symptoms within 2 to 5 weeks (Chou et al. 2019). In this experiment, loquat was used as an indicator plant to evaluate the existence of $P$. noxius inoculum in the infection site. Five approximately 2.5-year-old cuttings of E. japonica ( 80 to $90 \mathrm{~cm}$ in height, basal stem approximately $1 \mathrm{~cm}$ in diameter) were planted on 29 July 2018 at infection site C1, where the diseased tree, stump, and residual roots had been removed approximately 2 months a priori (30 May 2018) (Table 1 and Supplementary Fig. S1). Another five loquat cuttings planted at the $\mathrm{C} 2$ site ( $P$. noxius free based on soil plating and molecular detection) were used as controls. After 1 year (29 July 2019), all of the loquat trees were carefully harvested from the $\mathrm{C} 1$ and $\mathrm{C} 2$ sites. The root system of each plant was gently washed and then, photographed.

$P$. noxius infection in loquat roots was evaluated by tissue isolation and DNA detection. For each plant, one to two main roots (approximately 0.5 to $1.0 \mathrm{~cm}$ in diameter) and five to six fine roots (approximately 0.1 to $0.3 \mathrm{~cm}$ in diameter) were randomly sampled. The roots were cut into approximately 5 -cm segments and washed in sterile $\mathrm{dH}_{2} \mathrm{O}$ at $200 \mathrm{rpm}$ for $1 \mathrm{~h}$ with change of water every $10 \mathrm{~min}$. The samples were subsequently rinsed in $75 \% \mathrm{EtOH}$ for 30 to $60 \mathrm{~s}$, and then, they were rinsed twice in sterile $\mathrm{dH}_{2} \mathrm{O}$ for $60 \mathrm{~s}$. The surfacesterilized roots were cut into approximately $0.5-\mathrm{cm}$ segments and equally separated into two portions: one for tissue isolation and the other for DNA extraction. For tissue isolation, 42 main root segments and 28 fine root segments from each plant were transferred to 10 plates (seven approximately $0.5-\mathrm{cm}$ segments per plate) containing a modified $P$. noxius selective medium MA + 4 (20 g of malt extract, $20 \mathrm{~g}$ of agar, $10 \mathrm{mg}$ of benomyl, $10 \mathrm{mg}$ of dicloran, $100 \mathrm{mg}$ of chloramphenicol, and $500 \mathrm{mg}$ of gallic acid per liter) (Chang 1995a). After incubation at $30^{\circ} \mathrm{C}$ for a week, the isolation frequencies of $P$. noxius from the root segments were determined. The root samples pooled from each plant were ground into powder with liquid nitrogen. Three replicates of DNA extraction ( $0.5 \mathrm{~g}$ of pulverized root tissues per replicate) and $P$. noxius DNA detection were performed for each plant as described above.

The presence of $P$. noxius in the soil at sites $\mathrm{C} 1$ and $\mathrm{C} 2$ was evaluated by soil plating and DNA detection as described above. Soil samples were collected prior to and 1 year after transplanting the loquat cuttings. Before transplanting, the soils collected from 
five randomly chosen spots per site were tested. After 1 year, rhizosphere and non-rhizosphere soil samples from each plant were pooled and used for analysis. Soil plating was performed as described above, with aliquots of each dilution $\left(10^{-1}\right.$ and $\left.10^{-2}\right)$ spread onto five plates of MA + 5 medium. Soil DNA extraction ( $0.5 \mathrm{~g}$ of soil per sample) and detection of $P$. noxius DNA were conducted as described above.

\section{RESULTS}

Isolation of $P$. noxius from the soil at six BRR infection sites. Between October 2014 and March 2016, soil was sampled from each site two to nine times after the removal of diseased trees at eight BRR infection sites, A1 to A8 (Fig. 1). At site A2, soil was also sampled three times prior to the removal of the diseased tree. Soil plating tests revealed no $P$. noxius colonies in a total of 44 samples, suggesting that no or little viable $P$. noxius resided in the soil.

Isolation of $P$. noxius and detection of $P$. noxius DNA in the rhizosphere and non-rhizosphere soil from two BRR infection sites. To test whether $P$. noxius could disseminate from decayed roots to the surrounding soil environment, rhizosphere and non-rhizosphere soils were sampled from two infection sites: site B1, which had a living tree, and site B2, which contained only residual roots (Fig. 2A and B). The rhizosphere soils were specifically
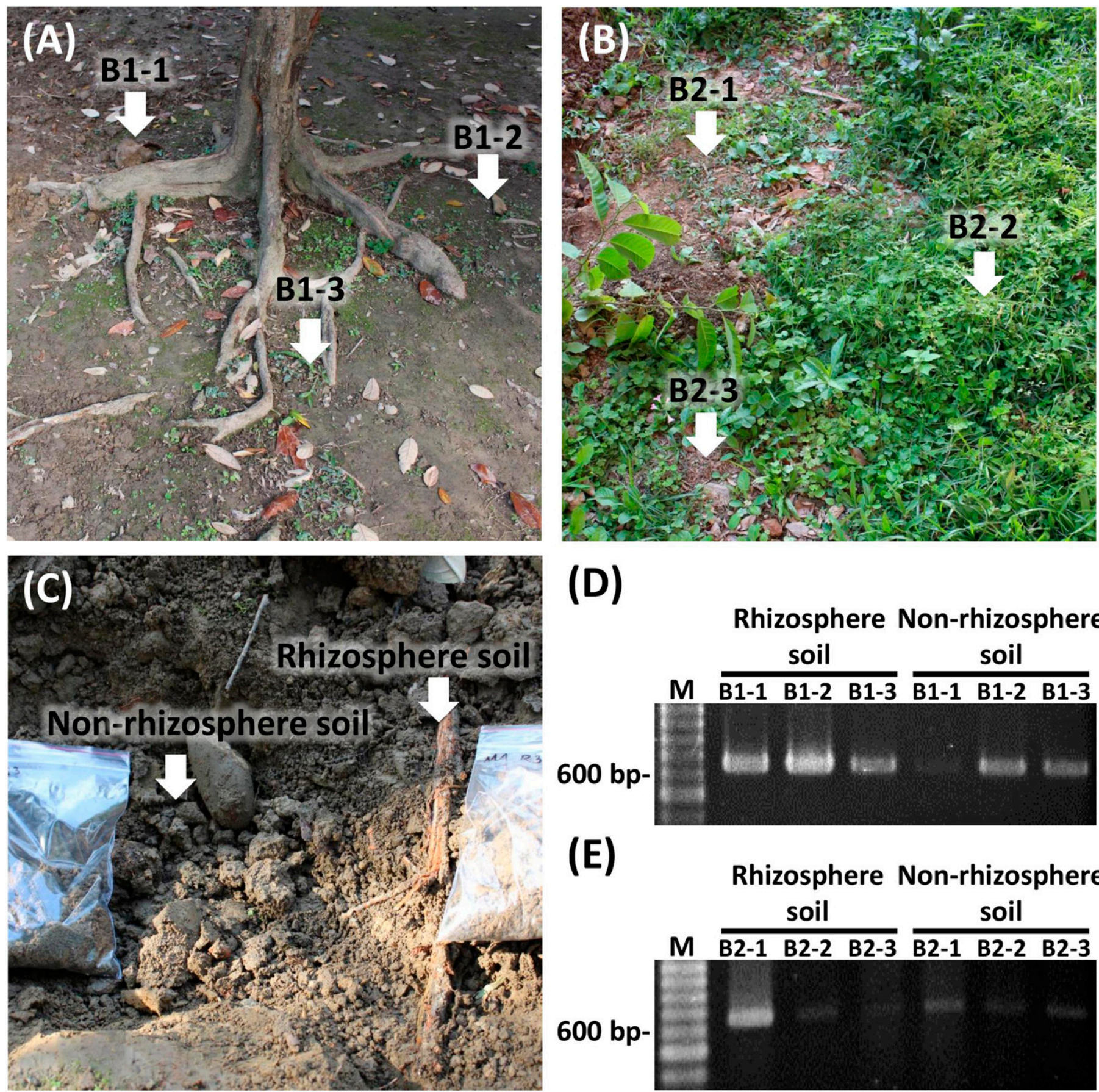

(D)

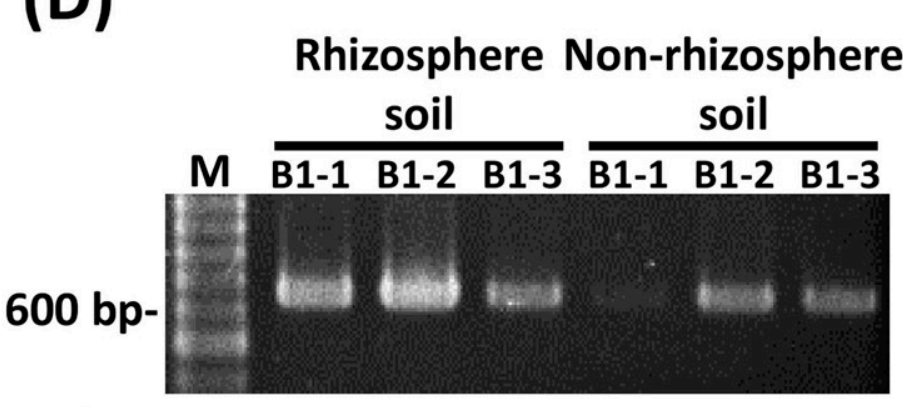

(E)

Rhizosphere Non-rhizosphere soil soil

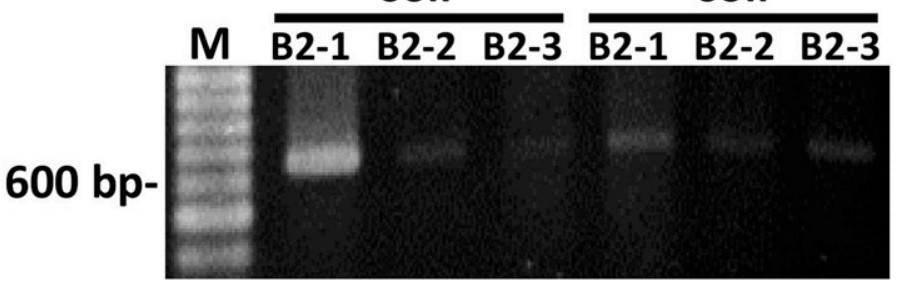

Fig. 2. Testing of rhizosphere and non-rhizosphere soils from brown root rot infection sites B1 and B2. A, Three spots were sampled (B1-1, B1-2, and B1-3) from the soil surrounding the living diseased tree located at site B1. B, Three spots were sampled (B2-1, B2-2, and B2-3) from site B2 (diseased tree removed). C, Rhizosphere soil was collected around a diseased root covered with a Phellinus noxius mycelial mat. Non-rhizosphere soil was collected approximately 20 to 30 $\mathrm{cm}$ away from the root. D and E, PCR amplification of the DNA extracted from rhizosphere and non-rhizosphere soils with $P$. noxius-specific primers G1-F and G1-R. M, 100-bp DNA ladder (Omics Biotechnology Co., Ltd.). 
sampled from the diseased roots showing white rot and with a $P$. noxius mycelial mat attached on the surface (Fig. 2C). No P. noxius colonies could be isolated from any rhizosphere or non-rhizosphere soil samples by soil plating. However, P. noxius DNA was detectable in all samples from both sites (Fig. 2D). The expected approximately 653-bp bands (Tsai et al. 2017; Wu et al. 2009) were sequenced using the dideoxy termination method to verify that the G1-F and G1-R primers specifically amplified $P$. noxius DNA. The relative amounts of $P$. noxius DNA in different samples can be roughly determined based on the brightness of the P. noxius-specific band. Based on this measure, higher levels of $P$. noxius DNA were observed in rhizosphere soil compared with non-rhizosphere soil and in the infection site with a living tree (site B1) compared with the infection site where the diseased stump had been removed 60 days prior to sampling (site B2).

Assay of $P$. noxius viability and detection of its DNA. The association between the presence of $P$. noxius DNA and viable $P$. noxius was investigated using field soil mixed with $P$. noxius arthrospores. The survival of $P$. noxius arthrospores was significantly affected by different treatments (Fig. 3A). At the beginning of the experiment, an average of 8.8 to $9.2 \times 10^{4} \mathrm{CFU} / \mathrm{g}$ of soil of $P$. noxius was detected by soil plating for all treatments. The quantities of viable $P$. noxius declined much more rapidly in the flooding (spores + flooding) and fumigation (spores + fumigation) treatments than in the control treatment (spores) in which the levels of $P$. noxius remained as high as $1.3 \times 10^{4}$ and $2.3 \times 10^{3} \mathrm{CFU} / \mathrm{g}$ of soil after 2 and 4 weeks of incubation, respectively. On the contrary, no viable $P$. noxius was recovered after 2 and 4 weeks of incubation in the flooding and fumigation treatments (the only exception was the detection of 2,000 CFU/g of soil of $P$. noxius in a single sample after 2 weeks of fumigation treatment). After 8 weeks of incubation, no $P$. noxius could be recovered from any of the treatments.

Figure $3 \mathrm{~B}$ shows the results from time course detection of $P$. noxius DNA in the soil after different treatments. P. noxius DNA could be detected even when no colonies were recovered by soil plating. The expected $P$. noxius band was clearly detected in samples after 2 and 4 weeks of flooding and fumigation treatments.
In the control treatment (spores), $P$. noxius DNA could be detected throughout the whole experimental period ( 8 weeks).

Use of loquat to detect $P$. noxius inoculum in the soil. No aboveground and underground symptoms were observed in the loquat plants growing at infection site $\mathrm{C} 1$ and control site $\mathrm{C} 2$ for 1 year. All of the loquats exhibited bushy branches and leaves, and no leaves were yellow or withered (Fig. 4A and B) (plants at site C1). The loquats were 80 to $90 \mathrm{~cm}$ in height, and the basal stems were approximately $1 \mathrm{~cm}$ in diameter at the beginning. After a year, the loquats at site $\mathrm{C} 1$ grew to 140 to $160 \mathrm{~cm}$ in height, and the basal stems were 2 to $3 \mathrm{~cm}$ in diameter. The loquats at site $\mathrm{C} 2$ were 120 to $130 \mathrm{~cm}$ in height, and the basal stems were 1 to $1.5 \mathrm{~cm}$ in diameter. Although differential growth rates were observed between sites, the root systems of all plants were healthy. There were abundant white and young lateral roots, and no necrosis or $P$. noxius mycelial mats were observed on the root surface (Fig. 4C shows the roots of a loquat at site $\mathrm{C} 1$ ). No $P$. noxius could be isolated from the loquat root tissues. Although the expected approximately 700-bp band was amplified from DNA extracted from loquat roots with the plantspecific primer pair ITS-An5 and ITS-An4, no PCR product could be amplified with the $P$. noxius-specific primer pair G1-F and G1-R (Fig. 4D, lanes 1 to 15). These results confirmed that the healthylooking root systems were free of $P$. noxius infection (data not shown for site $\mathrm{C} 2$ ).

As observed in sites A1 to A8, B1, and B2, no P. noxius colonies could be recovered from the soils in sites $\mathrm{C} 1$ and $\mathrm{C} 2$. At site $\mathrm{C} 1$, $P$. noxius DNA was detected before transplanting the loquats, but it was undetectable after a year. At site $\mathrm{C} 2, P$. noxius DNA was not detected before or after the transplanting of loquats (data not shown).

\section{DISCUSSION}

Although basidiospores and diseased host tissues have been recognized as important sources of $P$. noxius inoculum (Chang 1996; Chung et al. 2015, 2017; Hsiao et al. 2019a, b), the role of soil in the BRR disease cycle has remained unclear. In this study, soil dilution plating and molecular detection using specific primers
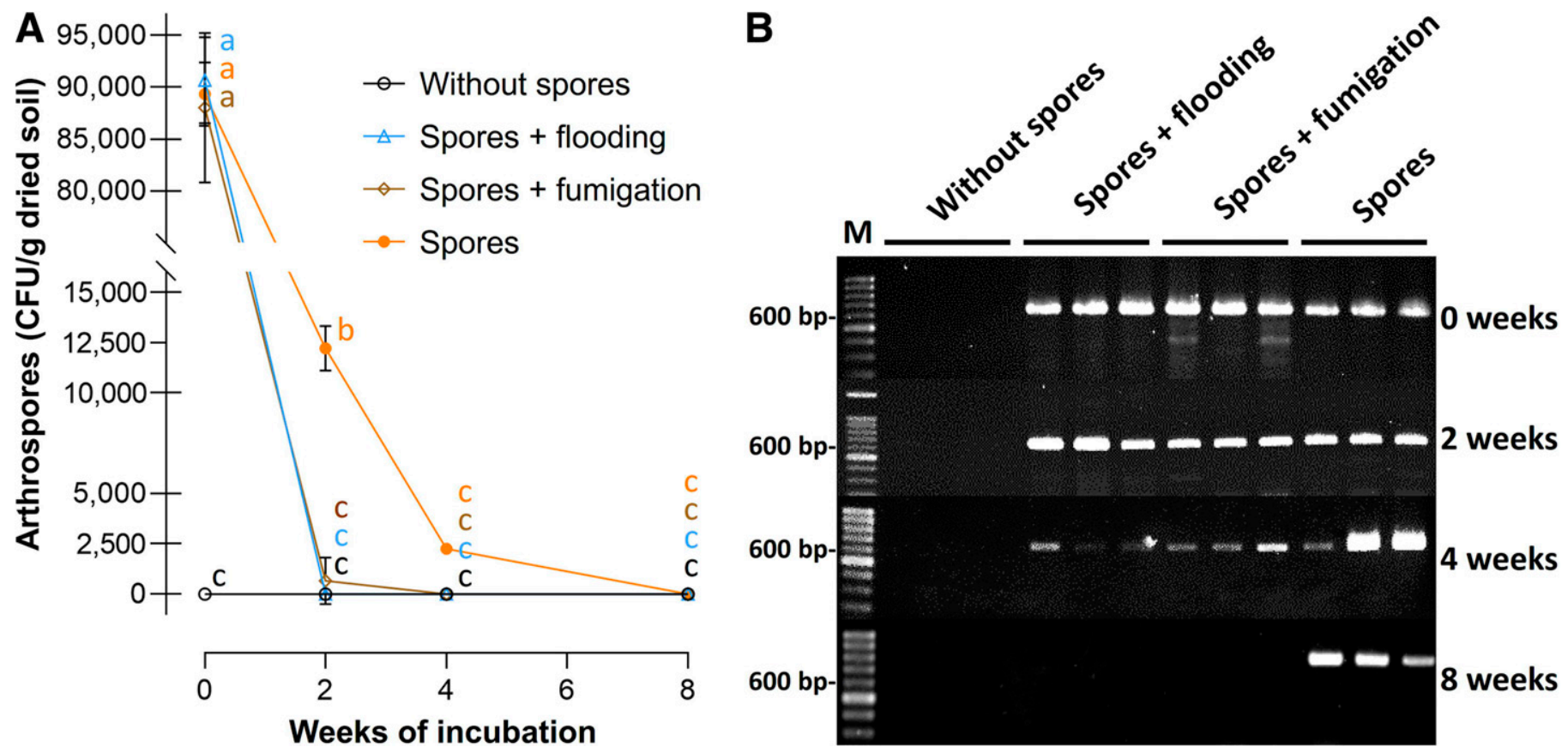

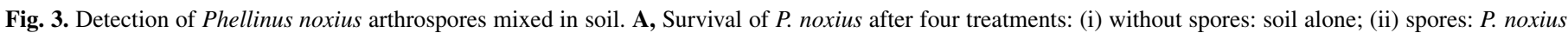

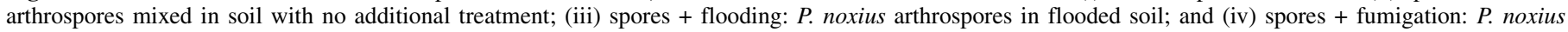

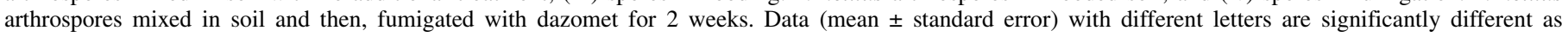

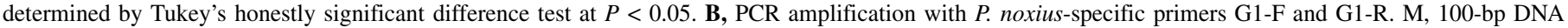
ladder (Omics Biotechnology Co., Ltd.). 
provided evidence that there was no or little viable $P$. noxius in the soil at BRR infection sites, regardless of whether the diseased tree was alive or had been removed. These results suggest that $P$. noxius resides almost entirely in infected wood and not in the soil. This is different from soilborne plant pathogens, such as Fusarium oxysporum f. sp. cubense and Sclerotinia sclerotiorum, which are able to survive in soil (without the host plant) in the form of resting structures (e.g., chlamydospores and sclerotia) for a long period of time (Merriman 1976; Ploetz 2006).

The survivability of root-rotting basidiomycetes in soil has also been investigated for A. mellea and $H$. annosum, which both share similar disease cycles with $P$. noxius (Ann et al. 2002). A. mellea grows through and survives in soil by forming black root-like rhizomorphs (Mihail and Bruhn 2005). H. annosum, however, could only extend for a few millimeters in microbially active soils (Srago and Cobb 1973). It has also been documented (without experimental data) that the laminated root rot pathogen $P$. sulphurascens could only grow short distances (millimeters) into soil from a colonized stump (Cook et al. 2013). In this study, P. noxius was not recovered from soil, even from the rhizosphere soil around heavily colonized roots covered with a mycelial mat. Chang (1996) also mentioned that $P$. noxius was not recovered from soils collected from the rhizospheres of diseased trees. This indicates that, similar to $H$. annosum and $P$. sulphurascens, $P$. noxius may have limited ability to grow into soil in the field. When grown on PDA, $P$. noxius produces arthrospores (formed by breakup of the mycelium) and trichocysts (specialized brown hyphae with numerous little protrusions bulging from the main hyphae) (Ann et al. 2002). Previous microscopic observations revealed that trichocysts but not arthrospores were present in naturally diseased root tissues (Tsai 2008) and artificially inoculated wood chips (Nicole et al. 1995). Despite close examination, arthrospores were not found in residual wood, root bark, fresh mycelial mats on roots and butts, or aerial hyphae growing on stump surfaces (Bolland 1984). The lack of asexual propagules may result in little chance of dissemination of $P$. noxius into the soil. Notably, although $P$. noxius basidiospores may have better survivability than mycelium (Chang 1996), we did not recover $P$. noxius from the soils collected from sites A7 and A8, where $P$. noxius basidiocarps were observed.

Molecular methods, such as conventional PCR (Wu et al. 2009), qPCR (Wang et al. 2016), loop-mediated isothermal amplification (Huang et al. 2014), and an oligonucleotide microarray system (Tzean et al. 2016), which are all based on $P$. noxious-specific ribosomal DNA ITS sequences, have been developed and used for the detection and diagnosis of $P$. noxius. Using qPCR to quantify $P$. noxius in soil samples, Wang et al. (2016) proposed that $P$. noxius is widely present in soils and may disseminate along with soil particles over long distances. However, in this study, although $P$. noxius DNA was successfully detected in both rhizosphere and non-rhizosphere soils collected from BRR infection sites, we could not isolate viable $P$. noxius from any of the soil samples. Using field soil mixed with $P$. noxius arthrospores, we also demonstrated that, when $P$. noxius in the soil was exterminated after flooding or dazomet fumigation treatment, the DNA of $P$. noxius remained detectable for a few weeks. It has been suggested that the decomposition of dead cells of microorganisms would release DNA into the soil; DNA can persist in soil for weeks to years, and relic DNA from dead organisms could constitute approximately $15 \%$ of soil DNA (Carini et al. 2016; Gustave et al. 2019). Therefore, although DNA-based technologies offer increased sensitivity, specificity, and effectiveness, a positive signal from molecular detection of $P$. noxius in soil should not be interpreted as the presence of living $P$. noxius entities or an indication of the need for disease control. Moreover, to inspect whether viable $P$. noxius
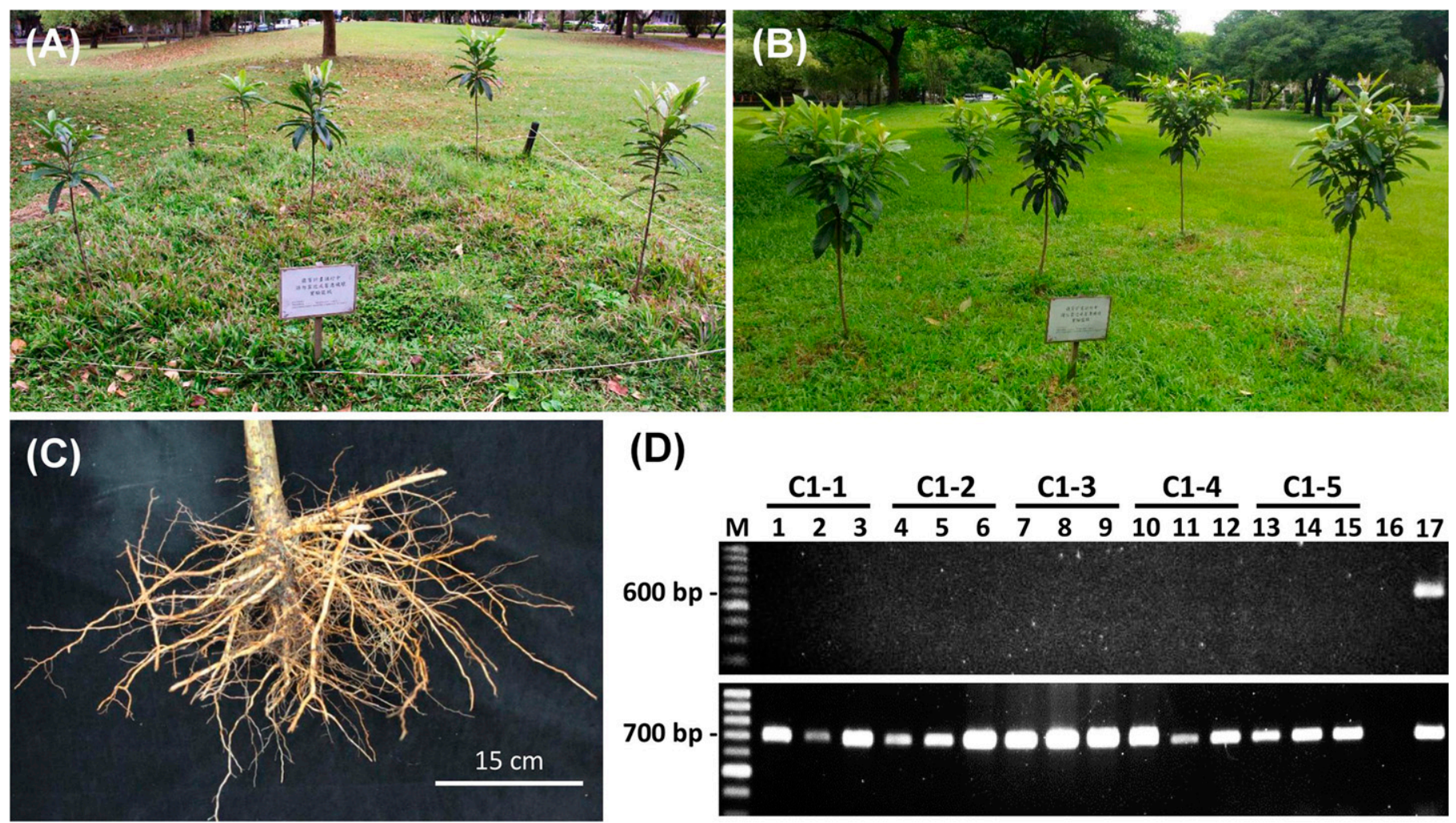

(D)
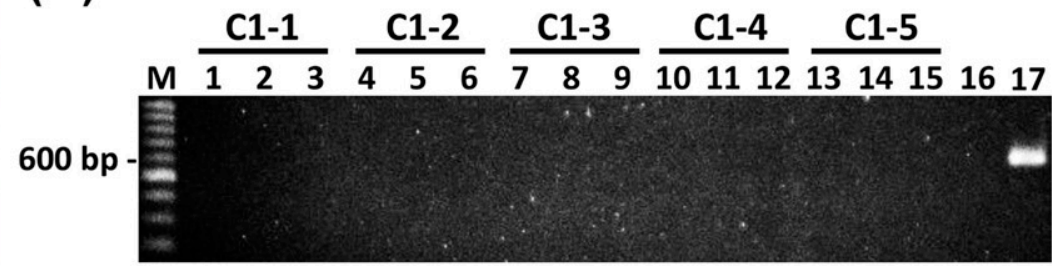

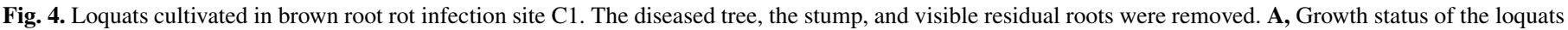

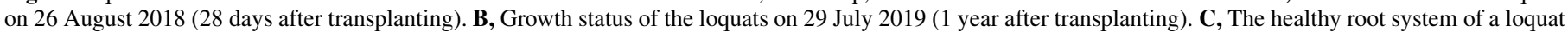

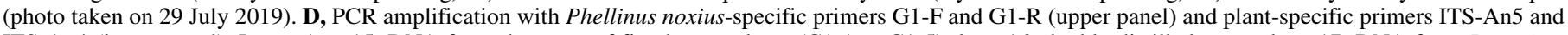

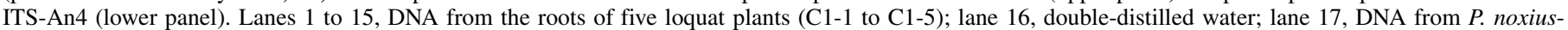

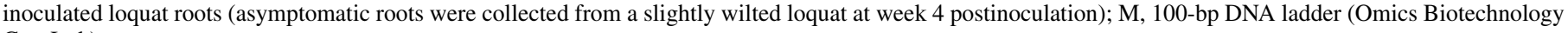
Co., Ltd.). 
exists in a certain area, one should focus on sampling and testing root tissues or wood debris, not the soil.

Field sanitation is a highly effective practice that keeps most diseases under control. For root rot diseases of woody plants, such as BRR, the implementation of field sanitation is relatively difficult. It is commonly found that people remove the aboveground parts of the diseased tree but leave the stump in place. The infected stumps can serve as a long-term reservoir (Chang 1996), and $P$. noxius often forms perennial basidiocarps on heavily colonized stumps. In many cases, even if an excavator is used to dig up the decayed stump and roots, many residual roots and wood remnants still remain in the field. In Taiwan, soil fumigation with dazomet ( $60 \mathrm{~g} / \mathrm{m}^{3}$ of soil, 40 to $60 \%$ soil moisture) is a widely applied measure for BRR management (Forestry Bureau COA 2013; Fu et al. 2012). However, because of the broad-spectrum biocidal activity of methyl isothiocyanate (the primary degradation product of dazomet), the potential harmful effect on nontarget organisms and ecosystems has always been a concern. Controversy also exists over whether soil fumigation is needed after thorough removal of the diseased stump and roots.

This study suggests that, as long as the wood debris can be thoroughly cleaned up, the onsite soil is not a source of inoculum for BRR. Under such a circumstance, the inoculum potential of $P$. noxius would be extremely low, and the trace amount of $P$. noxius could easily be diminished under stressed conditions or by antagonistic activities of other microorganisms. Indeed, highly susceptible loquat cuttings replanted in an infection site on the NTU campus that was cleaned up by simply removing the diseased stump and visible residual roots remained healthy for 1 year, and no viable $P$. noxius or $P$. noxius DNA could be detected in the root systems. It should be emphasized that, although chemical and biological control measures are available for BRR (Chou et al. 2019; Forestry Bureau COA 2013; Tsai et al. 2005), successful disease control relies mostly on careful and thorough cleanup of diseased host tissues. For example, the antagonistic potential of Trichoderma spp. against $P$. noxius has been shown on culture media, wood blocks, and loquat roots (Burcham et al. 2017; Chou et al. 2019; Ribera et al. 2016; Schwarze et al. 2012). Although bioremediation with Trichoderma spp. seems promising, Trichoderma spp. have relatively poor ability to decompose wood (Chou et al. 2019; Fukasawa et al. 2011). To accelerate the remediation of BRR-infested areas in a natural and sustainable way, future research could focus on developing new techniques to decompose onsite wood residuals.

\section{ACKNOWLEDGMENTS}

We thank Hsin-Hung Yeh for suggestions on the arthrospore assay; and Hung-Li Wang, I-Chen Tsai, Chieh-Yu Liu, Yi-Lin Chen, Wei-Yu Chuang, Kuan-Chuan Tseng, Ming-Jui Tsai, Dung-Yu Li, Cai-Ping Ye, Yi Cheng, I-Ting Huang, Yi-Xiu Chen, Zih-Yu Wei, Si-Huai Wang, Ming-Kai Hsu, Yi-Ting Chen, Zhi-Hua Li, and Ting-Hsuan Wu for participating in sample collection and soil plating.

\section{LITERATURE CITED}

Akiba, M., Ota, Y., Tsai, I. J., Hattori, T., Sahashi, N., and Kikuchi, T. 2015. Genetic differentiation and spatial structure of Phellinus noxius, the causal agent of brown root rot of woody plants in Japan. PLoS One 10:e0141792.

Ann, P. J., Chang, T. T., and Ko, W. H. 2002. Phellinus noxius brown root rot of fruit and ornamental trees in Taiwan. Plant Dis. 86:820-826.

Ann, P. J., Lee, H. L., and Huang, T. C. 1999a. Brown root rot of 10 species of fruit trees caused by Phellinus noxius in Taiwan. Plant Dis. 83:746-750.

Ann, P. J., Lee, H. L., and Tsai, J. N. 1999b. Survey of brown root disease of fruit and ornamental trees caused by Phellinus noxius in Taiwan. Plant Pathol. Bull. 8:51-60.

Bolland, L. 1984. Phellinus noxius: Cause of a significant root-rot in Queensland hoop pine plantations. Aust. For. 47:2-10.

Burcham, D. C., Abarrientos, N. V., Jr., Wong, J. Y., Ali, M. I. M., Fong, Y. K., and Schwarze, F. W. 2017. Field evaluation of Trichoderma spp. as a biological control agent to prevent wood decay on Benin mahogany (Khaya grandifoliola) and rain tree (Samanea saman) in Singapore. Biol. Control 114:114-124.

CABI. 2019. Phellinus noxius (Brown Tea Root Disease). Invasive Species Compendium. Wallingford, United Kingdom: CAB International. https:// www.cabi.org/isc

Carini, P., Marsden, P. J., Leff, J. W., Morgan, E. E., Strickland, M. S., and Fierer, N. 2016. Relic DNA is abundant in soil and obscures estimates of soil microbial diversity. Nat. Microbiol. 2:16242.

Chang, T. T. 1995a. A selective medium for Phellinus noxius. Eur. J. Forest Pathol. 25:185-190.

Chang, T. T. 1995b. Decline of nine tree species with brown root rot caused by Phellinus noxius in Taiwan. Plant Dis. 79:962-965.

Chang, T. T. 1996. Survival of Phellinus noxius in soil and in the roots of dead host plants. Phytopathology 86:272-276.

Cheng, T., Xu, C., Lei, L., Li, C., Zhang, Y., and Zhou, S. 2016. Barcoding the kingdom Plantae: New PCR primers for ITS regions of plants with improved universality and specificity. Mol. Ecol. Resour. 16:138-149.

Cherubini, P., Fontana, G., Rigling, D., Dobbertin, M., Brang, P., and Innes, J. L. 2002. Tree-life history prior to death: Two fungal root pathogens affect tree-ring growth differently. J. Ecol. 90:839-850.

Chou, H., Xiao, Y. T., Tsai, J. N., Li, T. T., Wu, H. Y., Liu, L. Y., Tzeng, D. S., and Chung, C. L. 2019. In vitro and in planta evaluation of Trichoderma asperellum TA as a biocontrol agent against Phellinus noxius, the cause of brown root rot disease of trees. Plant Dis. 103:2733-2741.

Chung, C. L., Huang, S. Y., Huang, Y. C., Tzean, S. S., Ann, P. J., Tsai, J. N., Yang, C. C., Lee, H. H., Huang, T. W., Huang, H. Y., Chang, T. T., Lee, H. L., and Liou, R. F. 2015. The genetic structure of Phellinus noxius and dissemination pattern of brown root rot disease in Taiwan. PLoS One 10:e0139445.

Chung, C. L., Lee, T. J., Akiba, M., Lee, H. H., Kuo, T. H., Liu, D., Ke, H. M., Yokoi, T., Roa, M. B., Lu, M. J., Chang, Y. Y., Ann, P. J., Tsai, J. N., Chen, C. Y., Tzean, S. S., Ota, Y., Hattori, T., Sahashi, N., Liou, R. F., Kikuchi, T., and Tsai, I. J. 2017. Comparative and population genomic landscape of Phellinus noxius: A hypervariable fungus causing root rot in trees. Mol. Ecol. 26:6301-6316.

Cook, R. J., Edmonds, R. L., Klopfenstein, N. B., Littke, W., McDonald, G., Omdahl, D., Ripley, K., Shaw, C. G., Sturrock, R., and Zambino, P. 2013. Opportunities for addressing laminated root rot caused by Phellinus sulphuracens in Washington's forests: A report from the Washington State Academy of Sciences in cooperation with the Washington State Department of Natural Resources. Washington State Academy of Sciences, Olympia, WA.

Doyle, J. J., and Doyle, J. L. 1987. A rapid DNA isolation procedure for small quantities of fresh leaf tissue. Phytochem. Bull. 19:11-15.

Forestry Bureau COA. 2013. Diagnosis and Management of Brown Root Rot Disease. Forestry Bureau COA, Executive Yuan, Taiwan.

Fu, C. H., Hu, B. Y., Chang, T. T., Hsueh, K. L., and Hsu, W. T. 2012. Evaluation of dazomet as fumigant for the control of brown root rot disease. Pest Manag. Sci. 68:959-962.

Fukasawa, Y., Osono, T., and Takeda, H. 2011. Wood decomposing abilities of diverse lignicolous fungi on nondecayed and decayed beech wood. Mycologia 103:474-482.

Gustave, W., Yuan, Z. F., Sekar, R., Toppin, V., Liu, J. Y., Ren, Y. X., Zhang, J., and Chen, Z. 2019. Relic DNA does not obscure the microbial community of paddy soil microbial fuel cells. Res. Microbiol. 170:97-104.

Hattori, T., Abe, Y., and Usugi, T. 1996. Distribution of clones of Phellinus noxius in a windbreak on Ishigaki Island. Eur. J. Plant Pathol. 26:69-80.

Hsiao, W. W., Hung, T. H., and Sun, E. J. 2019a. Newly discovered basidiocarps of Phellinus noxius on 33 tree species with brown root rot disease in Taiwan and the basidiospore variations in growth rate. Taiwania 64:263-268.

Hsiao, W. W., Hung, T. H., and Sun, E. J. 2019b. The pathogenicity of basidiospores of Phellinus noxius which causes brown root rot disease in Taiwan. Taiwania 64:189-194.

Huang, H., Sun, L., Bi, K., Zhong, G., and Hu, M. 2016. The effect of Phenazine-1-Carboxylic acid on the morphological, physiological, and molecular characteristics of Phellinus noxius. Molecules 21:613.

Huang, Y. H., Chen, C. H., Hung, T. H., Wu, M. L., and Chang, T. T. 2014. Development of the detection method for tree brown root rot disease based on the loop-mediated isothermal amplification (LAMP). Plant Pathol. Bull. 23:1-13.

Lee, H., Jang, Y., Choi, Y. S., Kim, M. J., Lee, J., Lee, H., Hong, J. H., Lee, Y. M., Kim, G. H., and Kim, J. J. 2014. Biotechnological procedures to select white rot fungi for the degradation of PAHs. J. Microbiol. Methods 97:56-62.

Merriman, P. R. 1976. Survival of sclerotia of Sclerotinia sclerotiorum in soil. Soil Biol. Biochem. 8:385-389.

Mihail, J. D., and Bruhn, J. N. 2005. Foraging behaviour of Armillaria rhizomorph systems. Mycol. Res. 109:1195-1207.

Nandris, D., Nicole, M., and Geiger, J. P. 1987. Variation in virulence among Rigidoporus lignosus and Phellinus noxius isolates from West Africa. Eur. J. Forest Pathol. 17:271-281. 
Nicole, M., Chamberland, H., Rioux, D., Xixuan, X., Ouellette, G. B., Blanchette, R. A., and Geiger, J. P. 1995. Wood degradation by Phellinus noxius: Ultrastructure and cytochemistry. Can. J. Microbiol. 41:253-265.

Ploetz, R. C. 2006. Fusarium wilt of banana is caused by several pathogens referred to as Fusarium oxysporum f. sp. cubense. Phytopathology 96: 653-656.

Ribera, J., Tang, A., Schubert, M., Lam, R., Chu, L., Leung, M., Kwan, H., Bas, M., and Schwarze, F. 2016. In-vitro evaluation of antagonistic Trichoderma strains for eradicating Phellinus noxius in colonised wood. J. Trop. For. Sci. 28:457-468.

Sahashi, N., Akiba, M., Ishihara, M., Ota, Y., and Kanzaki, N. 2012. Brown root rot of trees caused by Phellinus noxius in the Ryukyu Islands, subtropical areas of Japan. For. Pathol. 42:353-361.

Sahashi, N., Akiba, M., Ota, Y., Masuya, H., Hattori, T., Mukai, A., Shimada, R., Ono, T., and Sato, T. 2015. Brown root rot caused by Phellinus noxius in the Ogasawara (Bonin) islands, southern Japan - current status of the disease and its host plants. Australas. Plant Dis. Notes 10:33

Schwarze, F. W., Jauss, F., Spencer, C., Hallam, C., and Schubert, M. 2012. Evaluation of an antagonistic Trichoderma strain for reducing the rate of wood decomposition by the white rot fungus Phellinus noxius. Biol. Control 61:160-168.

Srago, M. D., and Cobb, F. W. 1973. Influence of soil biological factors on the mycelial growth of Fomes annosus. Pages 218-226 in: Proceedings of the Fourth International Conference on Fomes annosus. E. G. Kuhlman, ed. Southeastern Forest Experiment Station, Forest Service, U.S. Department of Agriculture, Athens, GA.
Tsai, J. N. 2008. Biological characteristics of Phellinus noxius and its molecular methods for diagnosis. Ph.D. dissert. National Chung Hsing University, Taichung, Taiwan.

Tsai, J. N., Ann, P. J., and Hsieh, W. H. 2005. Evaluation of fungicides for suppression of three major wood-decay fungi Phellinus noxius, Rosellinia necatrix and Ganoderma australe in Taiwan. Plant Pathol. Bull. 14:115-124.

Tsai, J.-N., Ann, P.-J., Liou, R.-F., Hsieh, W.-H., and Ko, W.-H. 2017. Phellinus noxius: Molecular diversity among isolates from Taiwan and its phylogenetic relationship with other species of Phellinus based on sequences of the ITS region. Bot. Stud. (Taipei, Taiwan) 58:9.

Tzean, Y., Shu, P. Y., Liou, R. F., and Tzean, S. S. 2016. Development of oligonucleotide microarrays for simultaneous multi-species identification of Phellinus tree-pathogenic fungi. Microb. Biotechnol. 9:235-244.

Wang, Y. F., Meng, H., Gu, V., and Gu, J. D. 2016. Molecular diagnosis of the brown root-rot disease agent Phellinus noxius on trees and in soil by rDNA ITS analysis. Appl. Environ. Biotechnol. 1:81-91.

White, T. J., Bruns, T. D., Lee, S. B., and Taylor, J. W. 1990. Amplification and direct sequencing of fungal ribosomal RNA genes for phylogenetics. Pages 315-322 in: PCR Protocols: A Guide to Methods and Applications. M. A. Innis, D. H. Gelfand, J. J. Sninsky, and T. J. White, eds. Academic Press, New York.

Wu, J., Peng, S. L., Zhao, H. B., Tang, M. H., Li, F. R., and Chen, B. M. 2011. Selection of species resistant to the wood rot fungus Phellinus noxius. Eur. J. Plant Pathol. 130:463-467.

Wu, M. L., Chang, T. T., Jaung, L. M., Hung, T. H., Chen, C. H., and Lin, L. D. 2009. Establishment of PCR rapid detection technique for tree brown root rot disease. Q. J. Chin. For. 42:239-247. 